\title{
Spatial variability of recruitment in the sand crab Emerita analoga throughout California in relation to wind-driven currents
}

\author{
Jennifer M. Diehl ${ }^{1}$, Robert J. Toonen ${ }^{2, *}$, Louis W. Botsford ${ }^{1}$ \\ ${ }^{1}$ Department of Wildlife, Fish and Conservation Biology, University of California, Davis, California 95616, USA \\ ${ }^{2}$ School of Ocean and Earth Science and Technology, The Hawai'i Institute of Marine Biology, \\ University of Hawai'i at Manoa, Coconut Island, PO Box 1346, Kane'ohe, Hawai'i 96744, USA
}

ABSTRACT: We compared recruitment of the sand crab Emerita analoga over 2 yr at 17 sites distributed along $>800 \mathrm{~km}$ of the California coastline. We hypothesized that larvae of benthic invertebrates are retained by water circulation near headlands, and then redistributed alongshore north of the promontories during synoptic-scale relaxation in upwelling winds. We tested for a negative relationship between recruitment and distance north of 4 headlands: Point Arena, Point Reyes, Monterey Peninsula, and Point Conception. We also examined patterns of recruitment at sites east of Point Conception, within the Southern California Bight (SCB). Recruitment magnitude was predictable at a given site within a recruitment season (June through October), but not between the 2 years at each site. Recruitment of E. analoga north of Point Conception was negatively correlated with site distance north of a headland in 1998, but not in 1999. Upwelling indices in 1998 were not significantly different from the long-term average either north of Point Conception or within the $\mathrm{SCB}_{\text {; in }}$ contrast, during 1999, upwelling was stronger than the $54 \mathrm{yr}$ average at all sites north of Point Conception, but not at those within the SCB. Thus, the upwelling-relaxation mechanism appeared to operate effectively from Point Arena to Point Conception in 1998, when upwelling and wind stress were within long-term average levels, but not in 1999, when upwelling and wind stress were anomalously high. However, in the SCB, we observed similar magnitude and spatial patterns of recruitment in both years. One implication of our results is that the California coast may be composed of separate retentive cells of populations separated by headlands, which enhances population persistence, but the extent of larval loss from these cells remains unknown.

KEY WORDS: Upwelling · Relaxation - Wind stress • Inner shelf $\cdot$ Larval transport $\cdot$ Settlement

Resale or republication not permitted without written consent of the publisher

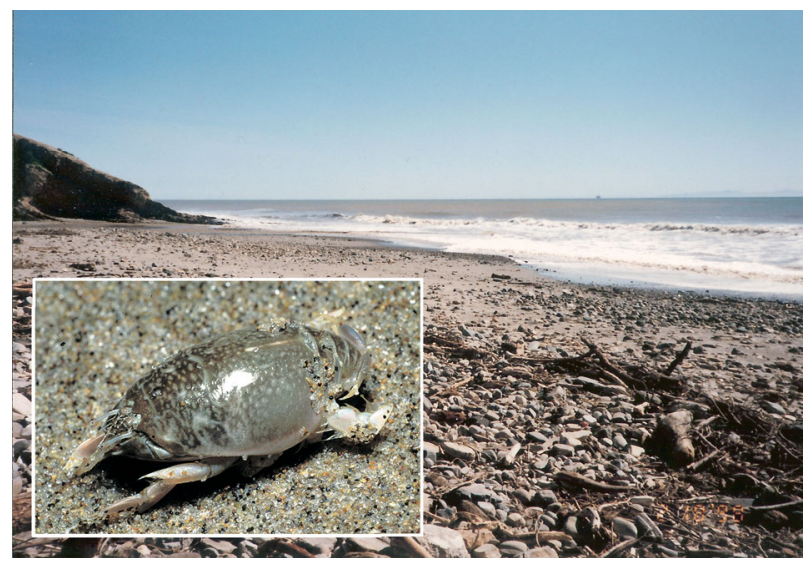

Gaviota State Beach, California, USA, where sand crabs Emerita analoga were sampled.

Photos: J. Diehl (beach), G. Jensen (crab)

\section{INTRODUCTION}

\section{Larval dispersal and recruitment}

Many populations of marine invertebrates, including crabs, sea urchins, barnacles, and some gastropods, have a spatially structured distribution composed of relatively distinct populations of sedentary benthic adults connected by dispersing pelagic larvae. Larval recruitment can influence marine populations by causing fluctuations in density (Roughgarden et al. 1985), variation in age structure (Doherty \& Fowler 1994), and changes in spatial distribution (Roughgarden et al. 1985). Accurate prediction of marine invertebrate population behavior is hampered by our limited knowledge of the spatial and temporal variability of larval recruitment at large scales. 
Variation in recruitment can be affected by variation in dispersal paths of larvae among adult populations. Although dispersal paths of large, short-duration dispersing larvae have occasionally been tracked directly (e.g. Carlon \& Olson 1993), dispersal patterns of larvae with lengthy dispersal periods are poorly known (Shanks et al. 2001, Kinlan \& Gaines 2003). One approach to studying larval dispersal paths, especially in the California Current System (CCS), is to sample physical oceanographic conditions and recruitment concurrently, then to examine the covariability between these so as to determine possible mechanisms influencing larval movement (Wing et al. 1995a,b, Miller \& Emlet 1997). A second approach is to sample recent recruitment in populations across a large spatial scale and correlate recruitment with oceanographic conditions over an appropriately corresponding time period to infer possible mechanisms affecting larval movement (Morgan et al. 2000).

In the present study, we investigated the effects of coastal circulation patterns on spatial and temporal variation in larval recruitment of the sand crab Emerita analoga along $\sim 800 \mathrm{~km}$ of the California coast. The life history of $E$. analoga is representative of many economically important marine species, and results of this study may be applicable to the conservation and management of other species, such as the Dungeness crab and the red sea urchin. Previous studies provide evidence that coastal topography influences coastal circulation and may be causally linked to spatial and temporal variation in recruitment and larval dispersal paths in northern California (Wing et al. 1995a,b, Miller \& Emlet 1997, Morgan et al. 2000). Here, we tested for a consistent pattern of recruitment that correlates with topographically influenced coastal circulation patterns associated with headlands along the California coast.

Specifically, we examined recruitment patterns of the sand crab Emerita analoga over a 2 yr period (1998 and 1999) at 17 sites along the California coast, in relation to the proximity to coastal headlands. Recruitment to the juvenile stage in the benthic population is more easily quantified in E. analoga populations than settlement; therefore, we focused on recruitment measurement. If post-settlement processes do not affect abundance of recruits differentially among populations (Wing et al. 1995a,b, Miller \& Emlet 1997, Morgan et al. 2000), we predicted a decline in recruitment from south to north within coastal regions separated by headlands. We examined intra- and inter-annual patterns of recruitment and patterns of spatial variability with regard to latitude and oceanographic features associated with headlands. Samples were collected during 1998 and 1999, which coincided with extremes in coastal oceanographic conditions: i.e. the second year of a strong El Niño event followed by a year of extremely high wind stress and upwelling (La Niña event). We document dramatic temporal variation in patterns of recruitment among populations and suggest this variability in nearshore oceanography may result in equivalent variability in larval dispersal paths.

\section{Coastal oceanography in the California Current System}

The effects of coastal circulation on recruitment of meroplanktonic larvae have been studied in the California Current System (CCS) for barnacles (e.g. Roughgarden et al. 1991, Pfeiffer-Hoyt \& McManus 2005), crabs (e.g. Wing et al. 1995a,b), sea urchins (e.g. Miller \& Emlet 1997), and rockfish (e.g. Carr \& Syms 2006). Part of the motivation for these studies is to understand how species with planktonic larvae can persist through the strong offshore and equatorward surface flows adjacent to the California coast during the upwelling season from April through August (Parrish et al. 1981, Largier et al. 1993, Gaylord \& Gaines 2000).

One hypothesis is that larvae are retained in oceanographic features associated with headland topography (Graham et al. 1992, Wing et al. 1998) and returned to adult populations during periods of reverse poleward flow that may occur when the upwelling winds weaken, or relax (Send et al. 1987, Wing et al. 1995a,b). However, unless relaxation events are accompanied by both weakening upwelling and a reversal to poleward winds, mean observed currents may not be predominantly onshore, and larvae may require other physical oceanographic processes for onshore transport. For example, because of the increased nearsurface stratification that results from warming during relaxation of upwelling, internal waves or bores may ultimately be more important than simple flow reversal for transporting larvae onshore during relaxation (Wing et al. 1995a,b).

Upwelling in the CCS is caused by strong equatorward, alongshore winds during spring, with relaxation events occurring approximately every 7 to $10 \mathrm{~d}$ when the winds weaken or reverse direction. Recent studies have highlighted the importance of short-term $(7$ to 10 d) variability in upwelling to invertebrate recruitment (Wing et al. 1995a,b, Morgan et al. 2000). Upwelling-relaxation flow was first associated with temporal variability in larval recruitment in central California, where barnacles appeared to settle when an offshore front containing larvae moved cross-shelf to 'collide' with the shore during relaxation events (Farrell et al. 1991, Roughgarden et al. 1991). These studies focused on the effect of relaxation in upwelling winds on cross-shelf transport to shore as the mecha- 
nism for temporal variation in recruitment. Settlement studies in northern California, however, have elucidated a response to upwelling relaxation that also involves alongshore flow and thus describes both dispersal and daily variability in settlement (Wing et al. 1995a,b). Inter-annual differences in oceanographic conditions affect the mechanism controlling larval movement, which can result in high variability in settlement of crabs and sea urchins (Lundquist et al. 2000).

In the present study, we consider how this upwelling-relaxation flow mechanism might operate along the California coastline. The major headlands within this geographic range are Point Arena, Point Reyes, Monterey Peninsula, and Point Conception (Fig. 1). We do not expect that the same physical and biological

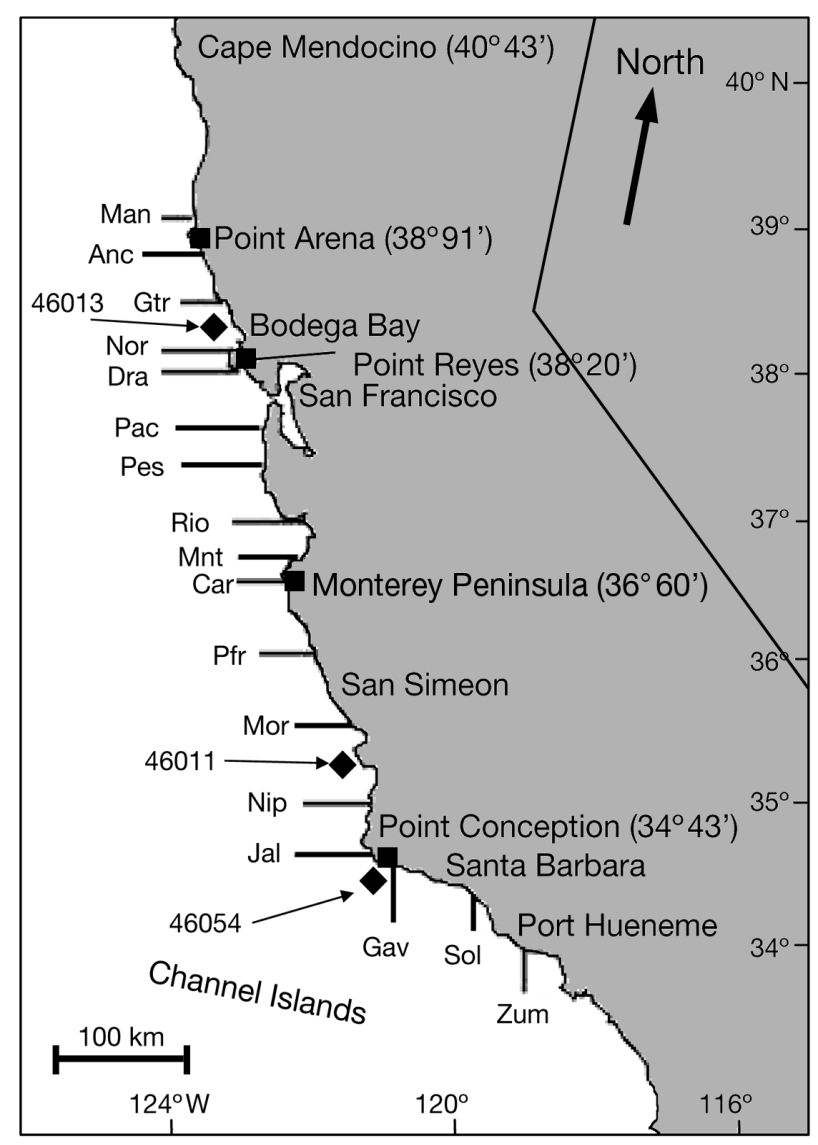

Fig. 1. Locations from which sand crab Emerita analoga recruits were sampled throughout Califonia: Man: Manchester State Beach, Anc: Anchor Bay Campground, Gtr: Goat Rock, Nor: North Beach, Dra: Drakes Beach, Pac: Pacifica, Pes: Pescadero State Beach, Rio: Rio del Mar Beach, Mnt: Monterey State Beach, Car: Carmel City Beach, Pfr: Pfieffer Beach, Mor: Morro Strand State Beach, Nip: Nipomo Dunes Preserve, Jal: Jalama Beach County Park, Gav: Gaviota State Park, Sol: Solimar Beach, Zum: Zuma Beach County Park. Headlands (ם) (north latitude in parentheses); positions of the NOAA buoys ( mechanism for larval retention and redistribution is repeated near all headlands in this region. Likewise, we acknowledge that the oceanographic currents on the continental shelf are generally quite complex relative to those observed in deeper water; thus, those small scale processes may act differently on larval transport relative to the upwelling dynamics seen in deeper water. In this study, we are therefore looking for potential mechanisms derived from similarities and differences around major headlands that may result in the observed spatial patterns of settlement of marine invertebrates due to retention and poleward flow during relaxation. We review what is known about nearshore circulation during upwelling and relaxation at each of the major headlands within our study region. We begin with Point Reyes because it is the most intensively investigated of headlands in this region (Wing et al. 1995a,b, 1998, Morgan et al. 2000).

\section{Point Reyes}

Intraseasonal current variability in the area is driven primarily by a combination of upwelling/relaxation dynamics, tidal and diurnal forcing, and inertial currents (Kaplan et al. 2005). During upwelling, larvae are retained in warm water features south of Point Reyes (Wing et al. 1998), then transported northward along the coast during relaxation of upwelling winds (Wing et al. 1995a,b). These northward flowing currents are forced by negative alongshore pressure gradients which are set up by the interaction of the wind-forced flow and the alongshore variations in shelf topography (Gan \& Allen 2002a,b). Crab larvae (especially Cancer spp.) tend to settle as the coastally trapped current moves poleward, so that sites north of Point Reyes receive larvae mainly during relaxation events. Therefore, sites closest to larval retention zones receive greater numbers of recruits each year than sites farther north (Wing et al. 1995b) because they are bathed in the larvae-rich poleward flow more frequently.

\section{Point Arena}

A potential retention zone exists near Point Arena (Fig. 2a), where a warm offshore eddy persists during the upwelling season (Washburn et al. 1993, Brink et al. 2000). Satellite images of sea surface temperatures (SST) indicate that during relaxation, warm water (red) from the offshore eddy generally flows poleward and toward shore, contacting the coast near Point Arena (Morgan et al. 2000); this differs from the flow pattern at Point Reyes where warm water flows from south of the headland around to the north (Fig. 2b). Thus, the 

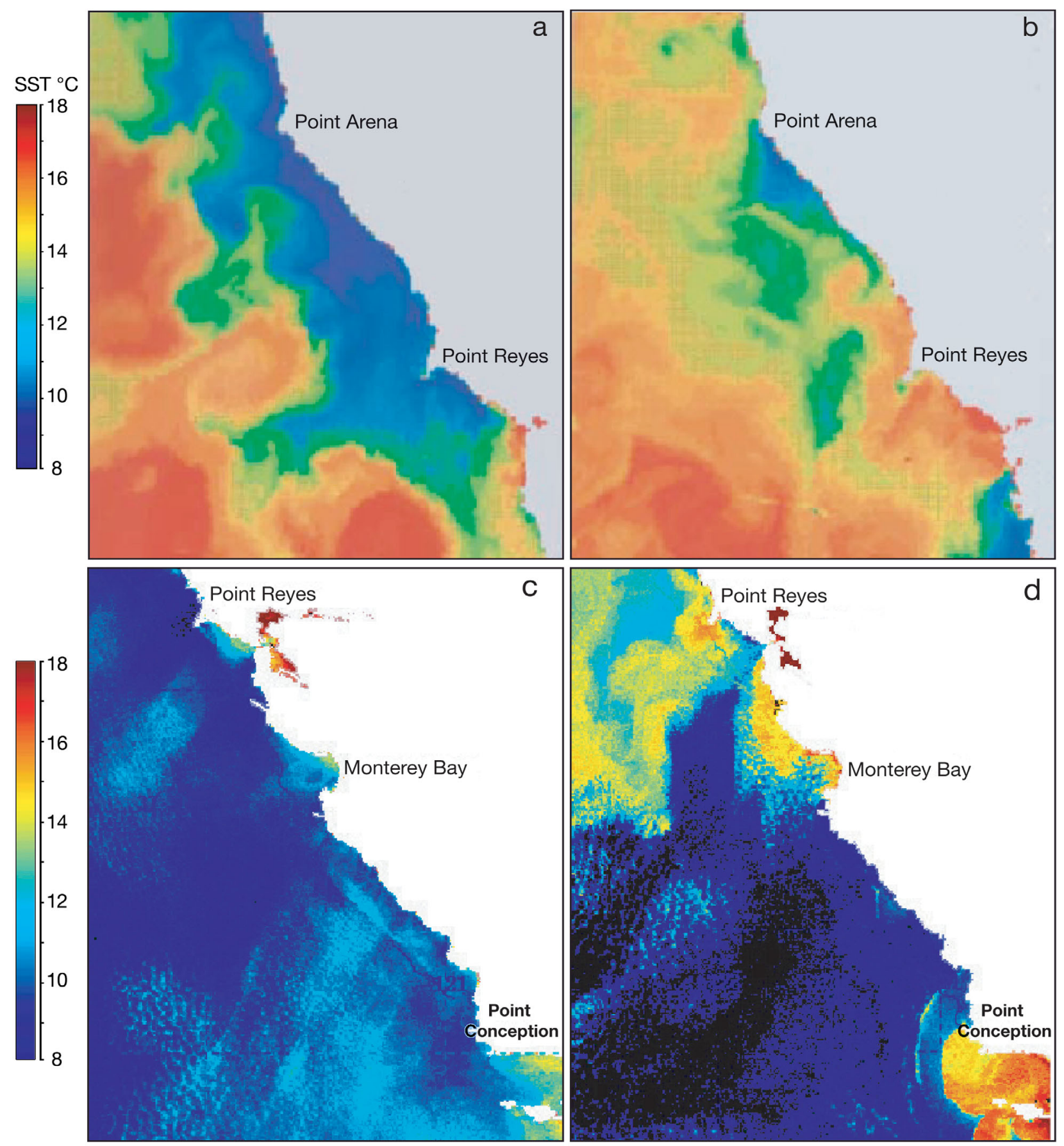

Fig. 2. AVHRR satellite images of sea surface temperature (SST) during (a) upwelling and (b) relaxation conditions around Point Arena and Point Reyes in northern California. (c) Coastwide upwelling wind conditions on Day 117 of 1998 shows upwelled water (dark blue) near Point Reyes, advecting into Monterey Bay, and around Point Conception. (d) Coastwide wind relaxation on Day 170 of 1998 shows poleward flow along shore (red) around Point Reyes, out of Monterey Bay, and around Point Conception. Images from archive at http://www2.mbari.org/kura/SST/SST_BRS.htm

region immediately south of Point Arena appears to be characterized by cold, upwelled water (Fig. 2b).

Morgan et al. (2000) studied size distributions of the red sea urchin Strongylocentrotus franciscanus and showed that recruitment was higher at sites north of both Point Reyes and Point Arena than at sites south of these headlands. The spatial patterns of recruitment observed for the red sea urchin are consistent with the hypothesis that coastal circulation patterns during relaxation events influence spatial variation in 
recruitment (Wing et al. 1995a,b, 1998, Morgan et al. 2000). Sites north of Point Arena and Point Reyes, where relaxation currents frequently contact the shore, received higher recruitment than sites south of these promontories (Wing et al. 1995a,b, 1998, Morgan et al. 2000).

\section{Monterey Peninsula}

During the upwelling season, when wind stress is alongshore and equatorward, water is upwelled north of Monterey Bay at Año Nuevo and advected south and east into Monterey Bay (Rosenfeld et al. 1994). In response to this upwelling, a large cyclonic gyre sets up within Monterey Bay, such that currents in the northern part of the bay flow predominantly northnorthwestward, in direct opposition to the south-eastward wind stress (Paduan \& Rosenfeld 1996, Storlazzi et al. 2003). Recent studies (Storlazzi et al. 2003, Drake et al. 2005) document that alongshore and cross-shore currents show a much more complex response to wind stress than previously suggested. However, sites near the bay's northern shore show the highest windtemperature coherence, and the recent studies were generally consistent with earlier observations that a front is established between the cool water in the southern and eastern sections of the bay and a warmer region of water in the northern bay (Graham 1993, Graham \& Largier 1997). This warm region of water (Fig. 2c), termed an 'upwelling shadow', is characterized by thermal stratification and slow cyclonic circulation (Graham \& Largier 1997, Storlazzi et al. 2003). When winds relax or reverse for several days, the upwelling shadow typically breaks down and the bay is flushed with low salinity warm water from the California Current (Graham \& Largier 1997), although subsequent work suggests that the action of internal tides may dominate the flow regimen (Storlazzi et al. 2003). Residence time of water within the upwelling shadow averages approximately 6 to $8 \mathrm{~d}$ with an overall poleward direction to the flow (Graham \& Largier 1997, Storlazzi et al. 2003). Similar salinity characteristics and internal flow patterns within Monterey Bay suggest that this warm water in the upwelling shadow began as upwelled water north of the bay (Graham et al. 1992, Rosenfeld et al. 1994). Given the observed current patterns, plankton that originates along the northern edge of Monterey Bay could be transported offshore and to the south during upwelling, become entrained within Monterey Bay and eventually within the upwelling shadow until it slowly circulates poleward out of the bay. The retention and circulation associated with the upwelling shadow in the northern part of Monterey Bay likely differs greatly from that in the southern part of Monterey Bay. For example, in the southern bay, Farrell et al. (1991) found that recruitment of barnacles coincided with wind relaxations and cross-shelf advection of warm low-salinity water. More detailed studies demonstrate the impact of spatial variation in current velocity, temperature and chlorophyll content on the duration of the larval period and dispersal trajectory of barnacle nauplii in the region (PfeifferHoyt \& McManus 2005).

\section{Point Conception}

Point Conception is the most southerly headland in our study. We considered patterns of recruitment at sites north of Point Conception separately from sites to the south because the California coastline changes from a north-south orientation to an east-west orientation at that point (Fig. 1). This topography has major impacts on the oceanography of the region. The strong northwesterly winds responsible for upwelling conditions along the California coast north of Point Conception increase in magnitude as they blow around Point Conception, then decrease as they continue along the east-west directed coastline (Dorman \& Winant 2000). Not much is known about the fine-scale surface flow, especially on the scale of individual relaxation events, directly north of Point Conception; however, we hypothesized that this area is influenced by relaxation flows in a similar fashion to the flows near Point Reyes and Point Arena based on observations of SST advanced very high resolution radiometer (AVHRR) satellite images during upwelling and relaxation (Fig. 2).

A large-scale overview of flow is provided from AVHRR satellite images of the coast of California including Point Reyes, Monterey Bay, and Point Conception (Fig. 2). During coastwide upwelling, coastal water is cold along most of the coast, and upwelling shadows can be seen in Monterey Bay and south of Point Conception (Fig. 2c). The warm water region south of Point Reyes is also an upwelling shadow, but in addition, warm, low salinity water flowing out of San Francisco Bay influences this region. During wind relaxation, warm water flow progresses to the north from south of Point Reyes, within Monterey Bay, and around Point Conception (Fig. 2d). We hypothesized that similar patterns of relaxation flow near these 3 headlands may result in similar patterns of recruitment to the north of each headland. Based on the AVHRR images and the results of recruitment studies around Point Reyes and Point Arena (Wing et al. 1995a,b, 1998, Morgan et al. 2000), we expected decreasing levels of recruitment with distance north of each headland. 


\section{Southern California Bight}

The Southern California Bight (SCB) region is widely thought to be under different oceanographic influences than the coast to the north of Point Conception (Dever 2004, Drake et al. 2005). The equatorward flowing California Current separates from the coastline at Point Conception and continues southward, but within the SCB an eddy forms from July through October, increasing retention between Point Conception and San Diego (Lynn et al. 1982). Most of the studies of coastal circulation south of Point Conception have focused on the Santa Barbara Channel (SB Channel) region, bounded by the California coastline from Point Conception to Port Hueneme on the north and by the 4 Channel Islands to the south (Harms \& Winant 1998, Winant et al. 2003, Dever 2004).

Mean surface water circulation in the SB Channel is a cyclonic eddy (anti-clockwise) concentrated in the western end of the channel (Harms \& Winant 1998). Water flows to the west on the northern shelf, and to the east further south, near the Channel Islands, but the magnitudes of these flows are not always equal. During upwelling, the southern boundary flow is strongest, so that mean flow is to the southeast; during relaxation in wind stress, a strong western jet flows along the north of the channel so that prevailing flow is to the northwest (Harms \& Winant 1998). Two other important flow regimes are: (1) cyclonic flow, when the magnitude of the east and west flows on opposite sides of the channel is equal, and (2) propagating cyclones, when small cyclonic eddies propagate westward across the SB Channel (Harms \& Winant 1998). Throughout the upwelling season (spring to summer), a repeated cycle of flow regimes occurs with a period of approximately $16 \mathrm{~d}$ : upwelling, cyclonic, relaxation, and weak flow (Harms \& Winant 1998).

The consequences for settlement patterns on the time scale of the flow regime cycle in the SCB are not known, but drifters have been used to indicate where flow may direct a passively floating object near the surface (e.g. Dever et al. 1998, Winant et al. 1999). By releasing drifters every few months in the SB Channel over a period of more than $3 \mathrm{yr}$, Winant et al. (1999) found distinct seasonal and depth differences in flow patterns (Winant et al. 2003). During the spring and summer, when equatorward wind stress was strong and upwelling flow dominated, drifters moved from the SB Channel into the Bight at the eastern end of the channel and between the Channel Islands. In the late fall and winter, when wind stress was weaker and relaxation flow dominated, a poleward current carried drifters westward along the northern shelf of the channel, then north around Point Conception to central California or out the western end of the channel and south into the Bight. In contrast, cyclonic flow tended to retain drifters within the channel. Average residence time for drifters over all seasons within the SB Channel was approximately $8 \mathrm{~d}$. Given these water current patterns, we hypothesized that larvae are more likely to be retained within the SB Channel during cyclonic flow, and distributed toward the southeast during upwelling and toward the northwest during relaxation. The consequences for spatial patterns in invertebrate recruitment are unknown, but rockfish recruitment is shown to be higher at the western end of the SB Channel than at the eastern end (Carr \& Syms 2006).

\section{Inter-annual variability}

Inter-annual patterns of settlement and recruitment can be strongly affected by inter-annual variability in oceanographic conditions. One of the challenges to understanding physical/biological interactions in the CCS is the effects of variability on inter-annual and longer time scales. The CCS is strongly influenced by El Niño events on inter-annual scales, as well as other mechanisms on decadal scales (e.g. Lynn et al. 1998, Botsford 2001). Our study was spatially extensive, but we could not expect to infer much about inter-annual variability from its limited temporal data $(2 \mathrm{yr})$. However, the period during which we sampled was a time of dramatic change in the CCS that has been of interest to physical oceanographers (e.g. Schwing et al. 2002), and we need to include these dramatic changing conditions in the interpretation of out results.

Both the Multivariate El Niño Southern Oscillation (ENSO) Index and the Northern Oscillation Index indicate that our sampling began (October 1997) during a mature El Niño event. The first summer of our sampling took place at the end of the El Niño event while the ocean was returning to average conditions. In contrast, by the time our second year of sampling began, a mature La Niña event was in progress, and that condition continued throughout the remainder of our study. Coastal conditions during the study period were strongly influenced by this El Niño/La Niña transition as well as variability on seasonal scales (Schwing et al. 2002). Although the first spring and summer of our sampling (1998) were well within the range of longterm average upwelling conditions for the northern California coastline, the spring of our second year had particularly strong and consistent upwelling winds throughout May and June which led to SSTs and sea levels that were some of the lowest recorded in the last $50 \mathrm{yr}$ (Schwing et al. 2002).

The El Niño/La Niña transition also had measured effects on species recruitment. Across nearly a decade 
(1992 to 1999) of sampling recruitment north of Point Reyes, recruitment of cancrid crab larvae had been positively correlated with upwelling. In contrast, average larval recruitment in 1999 was roughly an order of magnitude lower than in any previous year (Lundquist et al. 2000). Likewise, across much of California (Cape Mendocino to San Simeon), recruitment of such diverse taxa as barnacles and fishes appeared to be unusually high from May through September of 1997 (as the 1997/1998 El Niño event began) compared to the previous year or to 1999 (e.g. Menge 2000, Carr \& Syms 2006).

In this study, we examined temporal variation in spatial patterns of larval recruitment of the sand crab Emerita analoga in relation to the effects of local wind stress on nearshore oceanographic conditions for the years 1998 and 1999.

\section{MATERIALS AND METHODS}

Study species. The sand crab Emerita analoga is a northern hemisphere anomuran that inhabits sandy beaches between Alaska and Baja California (Efford 1976). E. analoga live in burrows only a few centimeters beneath the sand in the swash zone, the region of beach between the highest and lowest reach of the waves at a given time (Dugan et al. 2000). Sand crab populations along the west coast of the United States have a spatially-structured distribution, where rocky outcrops and other habitats lacking sand separate adult populations which are linked by pelagic larvae (Dugan et al. 1994).

Female Emerita analoga are ovigerous between February and October (Boolootian et al. 1959, Dugan et al. 1991), though a large percentage of females do not become ovigerous until at least May or June (J. Diehl pers. obs.). Females produce approximately one clutch of 50 to 45000 eggs per month during the breeding season (Boolootian et al. 1959, Dugan et al. 1991). Once hatched, the larvae are released into the water and probably spend at least 4 mo in the plankton before settling onto the beach (Johnson \& Lewis 1942, Efford 1970). Recruitment of megalopae into adult beach populations is always highest during summer; however, a low level of recruitment occurs almost yearround (Efford 1965, Barnes \& Wenner 1968).

Oceanographic data. To compare oceanographic conditions across the geographic range of the samples and between years, upwelling indices and alongshore wind stress values were calculated for 3 latitudes in 1998 and 1999. Monthly Bakun upwelling indices were obtained from the National Oceanic and Atmospheric Administration (NOAA) for latitudes $33^{\circ} \mathrm{N}, 36^{\circ} \mathrm{N}$, and $39^{\circ} \mathrm{N}$, which correspond approximately to San Diego in southern California, Big Sur in central California, and Point Arena in northern California, covering the full range of latitude used in this study. Average upwelling indices were calculated for April through September 1998 and 1999, and over the prior 54 yr period (1946 to 1999) using data from the archives maintained by the NOAA Environmental Research Division (www.pfeg.noaa.gov:16080/products/PFEL/modeled/ indices/upwelling/NA/).

Alongshore wind stress between years was compared using daily wind vectors collected by offshore NOAA buoys near Bodega Bay, Santa Maria, and Santa Barbara, at approximately $38^{\circ} \mathrm{N}, 35^{\circ} \mathrm{N}$, and $34^{\circ} \mathrm{N}$ latitude respectively (Fig. 1). The wind stress was calculated in a different compass direction $\left(317^{\circ}, 360^{\circ}\right.$, and $275^{\circ}$, respectively) for each site, based on alongshore coastline direction (Trenberth et al. 1990). Low or negative alongshore wind stress values are produced from low equatorward winds or poleward winds, respectively, and indicate a relaxation from upwelling conditions. Winds must be relaxed for a few days before the ocean responds and coastal currents reverse direction to flow poleward. Therefore, we used a $5 \mathrm{~d}$ running mean of the $\log$ (windstress +1 ) for these analyses. The log of wind stress was used because the residuals increase with increasing wind stress values, and our statistical analyses assumed homogeneity of variance (Sokal \& Rohlf 1981). Likewise, we chose a 5 d running average to filter high frequency events and concentrate on relaxation events that were likely to result in delivery of larvae under the upwelling-relaxation flow hypothesis. Finally, because our results indicated lower recruitment along the entire coast during the second year of our study, we also tested the hypothesis that this was caused by the reduced number of relaxations during that year of high incidence of upwelling winds. We used an analysis of variance (ANOVA) to compare the number of days during which relaxation conditions were present and the total number of relaxation events in 1999 and compared those to 1998.

Recruitment data. Density of the sand crab Emerita analoga was estimated bimonthly at 17 sandy beach sites distributed over $800 \mathrm{~km}$ of California coastline from October 1997 to October 1999 (Fig. 1). To investigate the effect of coastal topography on recruitment patterns, sites were located approximately 10, 50, 100, and $200 \mathrm{~km}$ north of each of the 4 headlands: Point Arena, Point Reyes, Monterey Peninsula, and Point Conception.

At each beach, 55 cores $(15 \mathrm{~cm}$ diameter, $20 \mathrm{~cm}$ deep) were taken within a $100 \times 20 \mathrm{~m}$ area inside the swash zone during a single tidal cycle. Locations of cores were determined in advance using a random number table. Carapace length (CL) of each crab 
caught in each core was measured with vernier calipers to the nearest $\mathrm{mm}$. Crabs were sexed before release. Recruits were identified on the basis of size. Recruits are first found at roughly 3 or $4 \mathrm{~mm} \mathrm{CL}$ and grow to approximately $8 \mathrm{~mm}$ in 2 mo (calculated from data in Fusaro 1978, Siegel 1984); therefore, individuals between 3 and $8 \mathrm{~mm}$ were considered to be new recruits that had settled between sampling periods.

Density of the total crab population and of recruits was calculated as the mean number of crabs per core. We also calculated an index of recent recruitment by dividing the density of recruits at a given site by the density of the rest of the population at that time.

Recruitment patterns. Temporal patterns of recruitment were analyzed with regard to intra-annual and inter-annual variability. Recruit density was log-transformed, $\log _{10}(x+1)$, to meet assumptions of normality for correlation analyses (Sokal \& Rohlf 1981). Intraannual consistency of site-specific recruitment was determined from correlations between sampling periods during the main recruitment season (June through October in both 1998 and 1999). We calculated correlations between June and August, and between August and October, for transformed recruit density at all sites. Correlations between years were calculated with the transformed density to determine whether recruitment at a site in one month of 1998 predicted recruitment during that same month in 1999; we computed correlations between years for June, August, and October.

Spatial patterns of recruitment were analyzed with regard to latitude and distance north of a headland using average recruitment index values from June through October of each year. The index of recent recruitment is a ratio, so we transformed it using an arcsine square root transformation (arcsine $\sqrt{\boldsymbol{X}}$ to meet assumptions of normality (Sokal \& Rohlf 1981). For sites north of Point Conception, correlations were conducted between the transformed index of recent recruitment and distance north from the closest headland for each site. We considered sites south of Point Conception separately and noted trends in recruitment index levels across space and between years. We used a 2-way ANOVA with repeated measures to compare transformed recruitment indices between years for sites north and south of Point Conception. There were no missing cells in the analysis. The factor year was treated as the repeated measure, and latitude was not. Jalama ('Jal' in Fig. 1) was included in the southern California group in the ANOVA because it is most likely to be affected by oceanographic conditions in the SB Channel. Although the north and south groups had different numbers of sites ( $\mathrm{n}=13$ and 4, respectively), the ANOVA had proportional subclass sizes and was analyzed accordingly (Sokal \& Rohlf 1981).

\section{RESULTS}

\section{Oceanographic data}

In both 1998 and 1999, upwelling indices are constant with latitude, but upwelling was higher in 1999 than in 1998 (Fig. 3). Because average upwelling indices decline with latitude, upwelling indices are higher with regard to the mean in northern California $\left(36^{\circ} \mathrm{N}\right.$ and $\left.39^{\circ} \mathrm{N}\right)$ than in southern California $\left(33^{\circ} \mathrm{N}\right)$. From the perspective of mean upwelling, 1998 was similar to a 'normal' year at all locations (i.e. within $1 \mathrm{SD}$ of values during the previous $54 \mathrm{yr}$ period). However, during 1999, the coast of California experienced extremely high upwelling indices, except for sites within the SCB. In the SB Channel, upwelling was high in 1999, but levels were still within $1 \mathrm{SD}$ of the 54 yr mean (Fig. 3).

The main upwelling period usually lasts from April 1 to July 1, corresponding to Days 91 to 182 of the year (Fig. 4). To compare the level of upwelling and relaxation in winds between years, we plotted wind stress for 1998 and 1999 from April 1 to September 30 (the recruitment period of Emerita analoga). Low or negative values indicate relaxation from upwelling winds. At all latitudes, the running mean of the log of alongshore windstress indicates that the coast experienced much more intense upwelling (apparent in the lack of zero and negative values of the log of wind stress) in 1999 than in 1998; thus, the resulting upwelling index was significantly above the 54 yr average for northern California (Fig. 3). However, despite the fact that extraordinarily high wind stress in 1999 resulted in anomalously high upwelling, and SSTs that were some of the lowest in the last $50 \mathrm{yr}$ (Schwing et al. 2002), there was no significant drop in relaxation events. With either a 3 or $5 \mathrm{~d}$ spin-up across a range of reasonable thresholds for defining a relaxation event, neither the number of relaxation events, the mean duration of
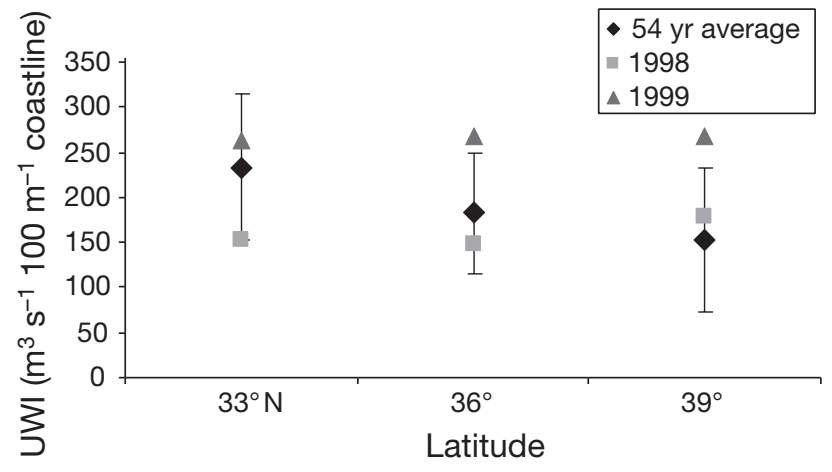

Fig. 3. Average upwelling indices at 3 latitudes on the coast of California April through September 1998 (), 1999 (४), and 1946 to $1999(\diamond)$. Error bars on 54 yr average points: \pm 1SD. Data source: NOAA archives, www.pfeg.noaa.gov 

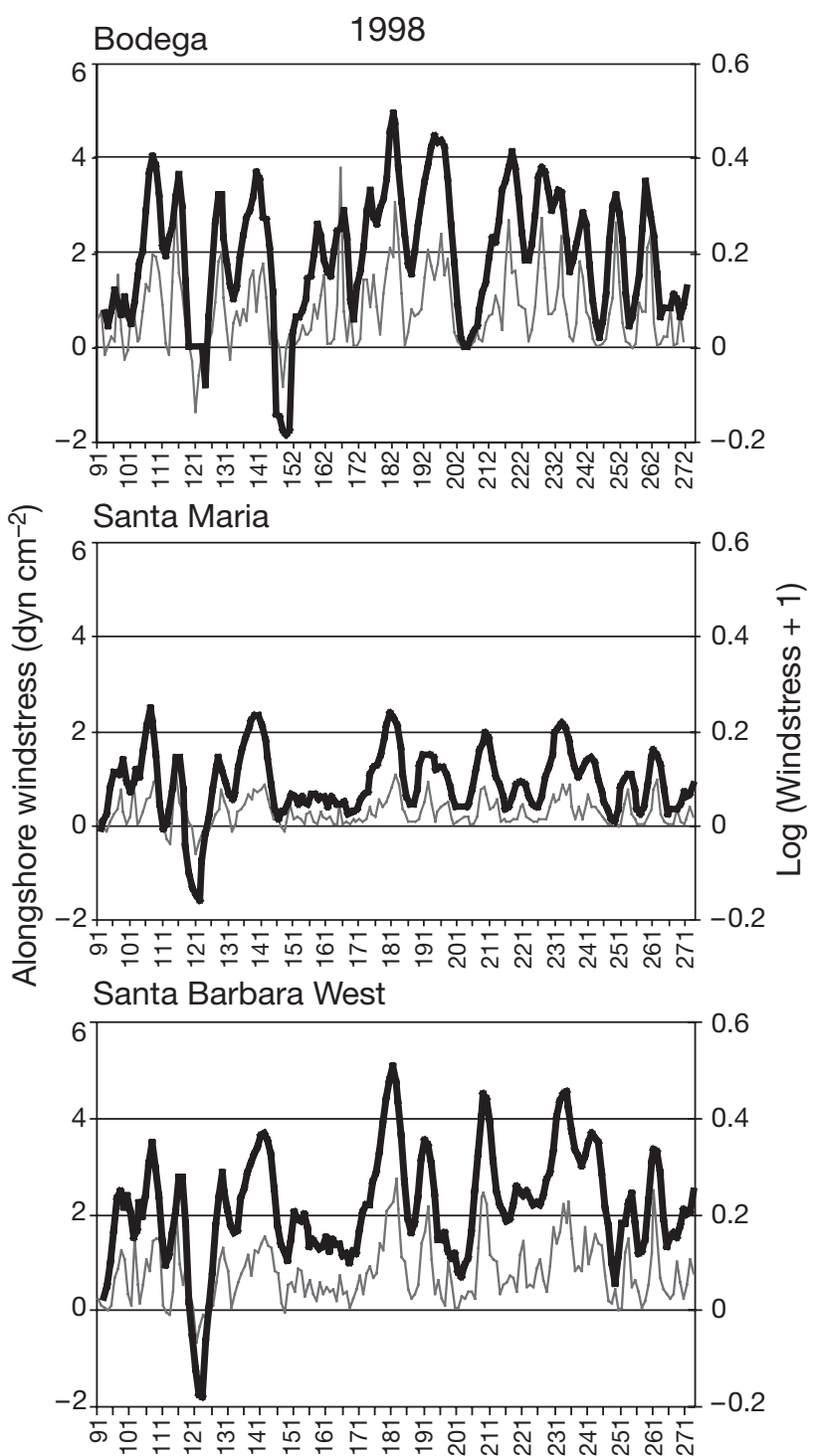

1999

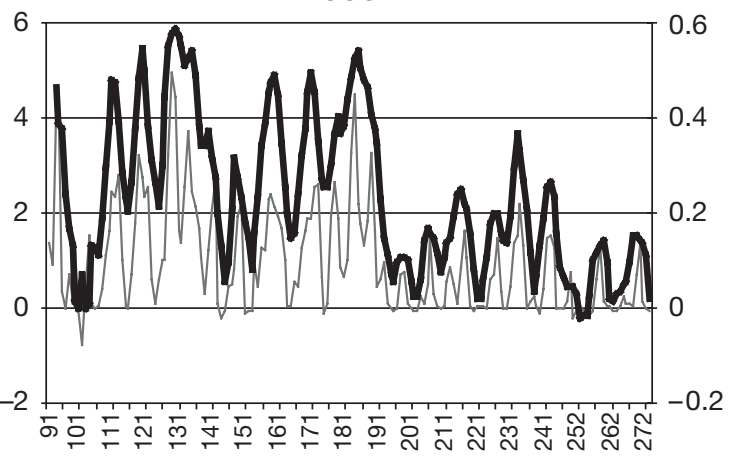

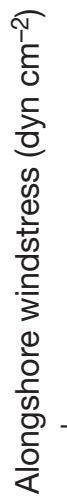

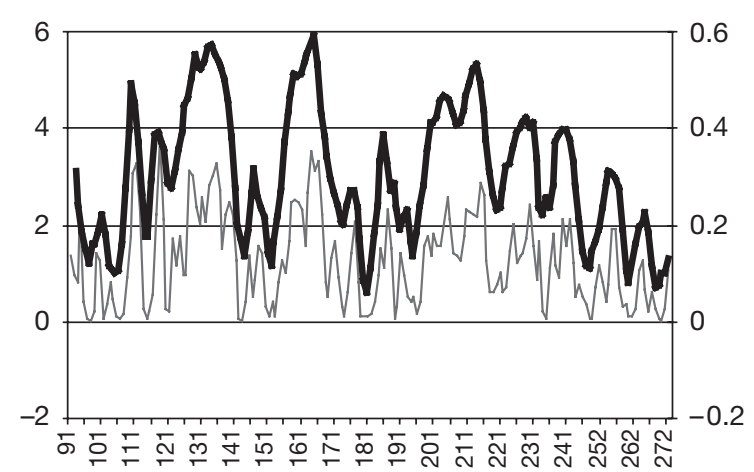

Day of the year

Fig. 4. Daily alongshore windstress (thin gray line) and 5 d running mean of log(windstress +1 ) (bold black line) at 3 sites on the California coast for 1998 and 1999. Bodega Bay: NDBC 46013, Santa Maria: NDBC 46011, Santa Barbara West: NDBC 46054 (Fig. 1). Low or negative values indicate relaxation from upwelling. Data source: NOAA, www.pfeg.noaa.gov

those events, nor the total number of days of relaxation differed significantly between 1998 and 1999, although there was a significant site by year interaction (data not shown).

\section{Recruitment data}

The density of both resident crabs and recruits fluctuated in all 17 populations; recruit density was highest in the summer and lowest in winter, but recruitment occurred throughout the year (Table 1). This pattern is apparent in densities from all sites averaged for each sampling time (Fig. 5). Because average recruit density over all sites was greater than 0.5 crabs per core from June through October in both 1998 and 1999, we considered June through October to be the recruitment season for Emerita analoga. Recruitment increases from June to August, then decreases from August to October in both years (Fig. 5).

\section{Recruitment patterns}

Sites with high recruitment relative to other sites in June and August of each year continued to receive high recruitment relative to other sites in August and October, respectively. Significant positive correlations 
Table 1. Recruit density (crabs core ${ }^{-1}$ ) from 17 sites in California during 2 yr of sampling. Sites are arranged from north to south (for definitions see Fig. 1), and location of major headlands is indicated. NA: sites that could not be sampled in a particular month

\begin{tabular}{|c|c|c|c|c|c|c|c|c|c|c|c|c|c|}
\hline & \multicolumn{2}{|c|}{1997} & \multirow[b]{2}{*}{ Feb } & \multirow[b]{2}{*}{ Apr } & \multirow{2}{*}{$\overline{\text { Jun }}^{1998}$} & \multirow{2}{*}{$8 \overline{\text { Aug }}$} & \multirow[b]{2}{*}{ Oct } & \multirow[b]{2}{*}{ Dec } & \multirow[b]{2}{*}{ Feb } & \multirow[b]{2}{*}{ Apr } & \multirow{2}{*}{$\begin{array}{l}1999 \\
\text { Jun }\end{array}$} & \multirow[b]{2}{*}{ Aug } & \multirow[b]{2}{*}{ Oct } \\
\hline & Oct & Dec & & & & & & & & & & & \\
\hline MAN & 0.18 & 0.02 & NA & $0.01^{\mathrm{a}}$ & 0.04 & 3.53 & 0.29 & 0 & 0 & 0 & 0 & 0 & 0 \\
\hline \multicolumn{14}{|c|}{ Point Arena } \\
\hline ANC & 0.20 & $0.16^{\mathrm{a}}$ & NA & $0.08^{\mathrm{a}}$ & 5.40 & 10.22 & 1.20 & 0.02 & 0 & 0 & 0 & 0.02 & 0.35 \\
\hline GTR & $0.50^{\mathrm{a}}$ & $0.26^{\mathrm{a}}$ & $0^{\mathrm{a}}$ & NA & NA & 0.34 & $0.17^{\mathrm{a}}$ & 0.04 & 0 & 0 & $0.12^{\mathrm{a}}$ & 0.47 & 0.11 \\
\hline NOR & 0.22 & 0.03 & NA & 0.02 & 0.32 & $2.17^{\mathrm{a}}$ & 0.07 & 0 & 0 & 0 & 0 & 0 & 0 \\
\hline \multicolumn{14}{|c|}{ Point Reyes } \\
\hline DRA & 0 & 0.02 & NA & 0 & 0.01 & 0.07 & 0 & 0 & 0 & 0 & 0 & 0 & 0 \\
\hline PAC & 1.12 & 0.02 & 0 & 0.055 & 0.18 & $2.72^{\mathrm{a}}$ & 1.00 & 0 & 0.02 & 0 & 0 & 0.04 & 0 \\
\hline PES & 0 & 0.39 & $0^{\mathrm{a}}$ & 0 & 2.83 & $18.88^{\mathrm{a}}$ & $6.45^{\mathrm{a}}$ & 0.18 & 0.06 & 0.07 & 0.01 & 1.01 & 0.02 \\
\hline RIO & $0.32^{\mathrm{a}}$ & 0.03 & 0 & 0 & 1.29 & $0.81^{\mathrm{a}}$ & 0.84 & 0.02 & 0 & 0 & 0 & 0.04 & 0.09 \\
\hline MNT & 0.18 & 0.04 & 0 & 0.22 & 3.84 & 3.04 & 0.59 & 0.55 & 0.40 & 0.11 & 0.04 & 0 & 0 \\
\hline \multicolumn{14}{|c|}{ Monterey Peninsula } \\
\hline CAR & $0^{\mathrm{a}}$ & 0 & 0.02 & 0 & 0 & 0 & 0.04 & 0.02 & 0 & 0 & 0.02 & 0 & 0 \\
\hline PFR & 0.31 & 0 & NA & NA & 0.27 & 0.29 & 2.42 & 2.05 & 0.01 & 0.07 & 0.01 & 0.47 & 0.02 \\
\hline MOR & $0.10^{\mathrm{a}}$ & $0^{\mathrm{a}}$ & NA & NA & $1.5^{\mathrm{a}}$ & 0.06 & 0.04 & 0 & 0 & 0 & $0.08^{\mathrm{a}}$ & 0.02 & 0 \\
\hline NIP & 0.24 & 0.05 & NA & NA & $12.17^{\mathrm{a}}$ & $9.34^{\mathrm{a}}$ & 0.47 & 0.02 & 0.04 & 0.12 & 0.33 & 4.15 & 0.11 \\
\hline JAL & 0.49 & 0.27 & 0 & $0^{\mathrm{a}}$ & 0.22 & 10.62 & 2.13 & 0.02 & 0.05 & 1.27 & 0.01 & 24.92 & 0.77 \\
\hline \multicolumn{14}{|c|}{ Point Conception } \\
\hline GAV & 3.80 & NA & NA & NA & 1.40 & 6.77 & 0.67 & 0.33 & 0.03 & 0.07 & 28.10 & 17.38 & 4.36 \\
\hline SOL & $0.18^{\mathrm{a}}$ & 0.01 & $0^{\mathrm{a}}$ & 0 & 0 & 2.11 & 0.31 & 0 & $0.01^{\mathrm{a}}$ & 0.35 & 21.29 & 7.42 & 0.70 \\
\hline ZUM & 0 & 0 & $0^{\mathrm{a}}$ & 0.02 & 0.55 & 2.16 & 0.08 & 0.02 & 0 & 4.85 & 4.77 & 13.12 & 3.74 \\
\hline
\end{tabular}

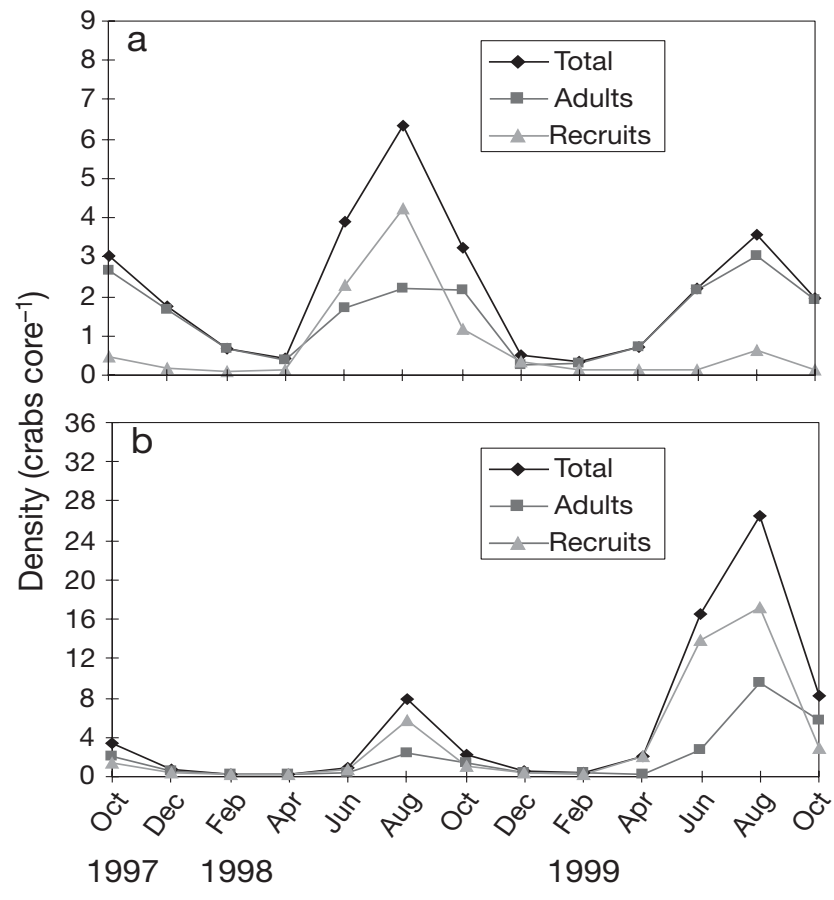

Fig. 5. Emerita analoga. Mean density (over 17 sites) of total $(\bullet)$, mature and juvenile crabs $(\square)$, and new recruits $(\Delta)$ averaged across sites (a) north, and (b) south, of Point Conception. Note different $y$-axes scales

$(\mathrm{p}<0.05)$ between months within each year indicate consistent intra-annual spatial pattern of recruitment of Emerita analoga (Fig. 6). However, overall recruitment was higher from June to August than from
August through October (Fig. 6a,c versus 6b,d). In 1999, most of the sites north of Point Conception had consistently low recruitment throughout the season. The positive correlations in 1999 were determined largely by a few sites with recruit densities greater than 7 recruits per core; these 4 sites were the most southern sites in the sampling range: Jalama, Gaviota, Solimar, and Zuma.

No significant correlations $(p>0.1)$ were found across sites for each month between years (data not shown). Throughout California, density of recruitment at a site in 1999 is not predicted by recruitment in 1998. In June and October 1999, recruitment density was less than 1 recruit per core except at the 3 sites south of Point Conception.

To characterize spatial variability of annual recruitment, the index of recent recruitment was averaged over June, August, and October for each year (Fig. 7). Because recruitment levels decreased significantly in northern California from 1998 to 1999, but remained similar in southern California between years, recruitment was negatively correlated with latitude in 1999 $\left(y=-8.5 x+328.3, r^{2}=0.7, p<0.01\right)$ but not in 1998 $\left(y=-2.2 x+121.4, r^{2}=0.05, p>0.5\right)$ (Fig. 8a,b).

To test for the contribution of large-scale latitudinal trends to the observed patterns of recruitment in relation to headlands, we removed the latitudinal trend in recruitment (Fig. 8) and conducted correlation analyses between the residuals from the latitude plots and distance north of a headland. The transformed recruitment index was significantly negatively correlated 


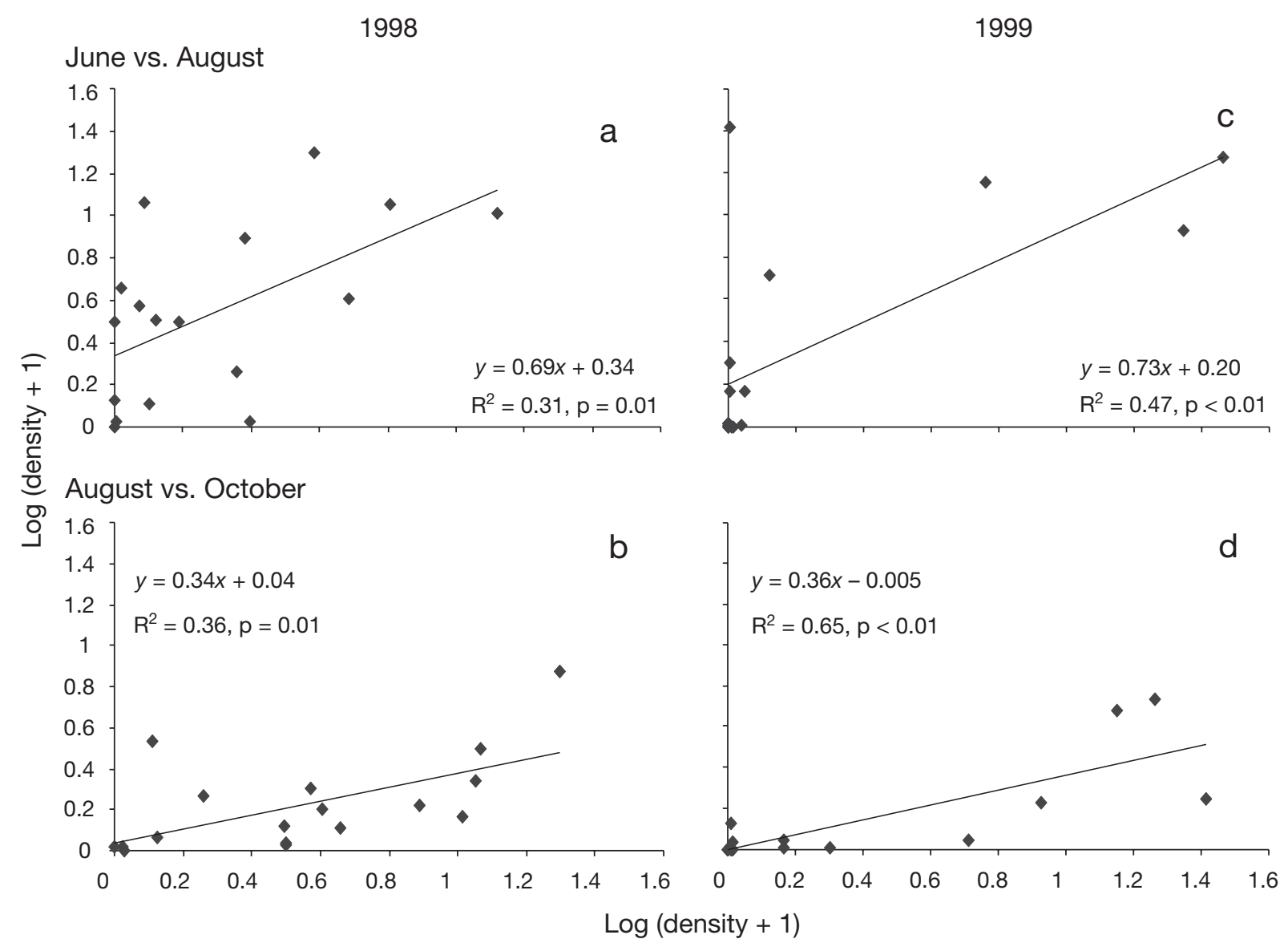

Fig. 6. Emerita analoga. Correlations of transformed density of E. analoga sampled from June to August and August to October in each of 1998 and 1999. Significant positive correlations in all cases suggest consistent relative levels of recruitment at a given site throughout the recruitment season in both years

with site distance north of the nearest headland to the south for all sites north of Point Conception in 1998 ( $y=$ $\left.-0.1 x+50.8, r^{2}=0.5, p<0.01\right)$, but the relationship was not significant in $1999\left(y=-0.01 x+12.8, r^{2}=0.009, p>\right.$ 0.5) (Fig. 8c,d). Removing the latitudinal trend in recruitment did not have much of an effect on the slope of the relationship with regard to headlands in either $1998\left(y=-0.1 x+12.9, \mathrm{r}^{2}=0.5, \mathrm{p}<0.01\right)$ or $1999(y=$ $\left.-0.03+2.8, \mathrm{r}^{2}=0.06, \mathrm{p}>0.5\right)$.

The 2-way ANOVA for year and coastal region (latitude) found significant differences due to year $\left(F_{1,15}=\right.$ $7.9, \mathrm{p}<0.05)$ but not region $\left(F_{1,15}=2.702, \mathrm{p}>0.1\right)$. However, the significance of the interaction term $\left(F_{1,15}=5.7, \mathrm{p}<0.05\right)$ indicates that different coastal regions responded differently in 1998 than in 1999. This appears to derive from the fact that the recruitment index in southern California averaged among the 3 sites did not differ between 1998 and 1999, but the average recruitment index for sites north of Point Conception was significantly lower in 1999, than it had been in 1998 (data not shown). In both 1998 and 1999, the recruitment index indicated the same spatial pattern of recruitment in southern California; the recruitment index was highest at Gaviota, $13 \mathrm{~km}$ east of Point Conception, and decreased at sites further to the east as well as at Jalama, $13 \mathrm{~km}$ north of the point (Figs. 7 \& 8).

The consistent positive correlation between upwelling indices and larval recruitment in northern California suggests that the reduced recruitment observed in 1999 may be due to fewer relaxation events. However, as outlined above, there is no significant difference in the number of relaxation events, the mean duration of those events, or the total number of days of relaxation between years, which discounts this hypothesis. Another hypothesis for low recruitment levels north of Point Conception during 1999 may be reproductive failure. For example, the porcelain crab Petrolisthes cinctipes, another anomuran in California, was not ovigerous until July in 1999, though they are usually ovigerous by March (Toonen 2001). To address this possibility, we calculated the percent of 


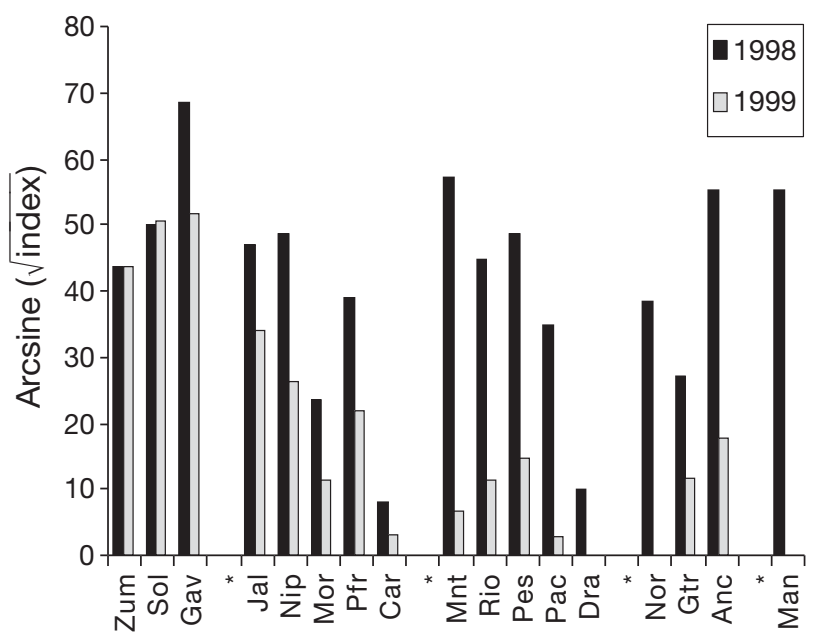

Fig. 7. Emerita analoga. Transformed indices of recent recruitment of E. analoga at all sites in each of 1998 and 1999. Sites are arranged (left to right) from south $\left(34^{\circ} \mathrm{N}\right)$ to north $\left(39^{\circ} \mathrm{N}\right)$ on the $x$-axis and correspond to those shown in Fig. 1. ${ }^{*}$ Location of the major headlands (left to right): Point Conception, Monterey Peninsula, Point Reyes and Point Arena ovigerous females (averaged over all sites north of Point Conception) from June through October in both 1998 and 1999. Arcsine square-root transformed values of average percent of ovigerous females were not significantly different in the same month between years (ANOVA: June 1998 and 1999, p > 0.5; August 1998 and 1999, p > 0.1, October 1998 and 1999, p = 0.05). In fact, the proportion of ovigerous females was slightly higher in 1999 than 1998 (data not shown). Together with the fact that adult density was similar in 1998 and 1999 (Fig. 5), a reduced abundance of ovigerous crabs in 1999 is also unlikely to account for the low recruitment observed north of Point Conception.

\section{DISCUSSION}

Recruitment of Emerita analoga occurred throughout the year, but higher levels were present between June and October. A greater number of recruits arrive
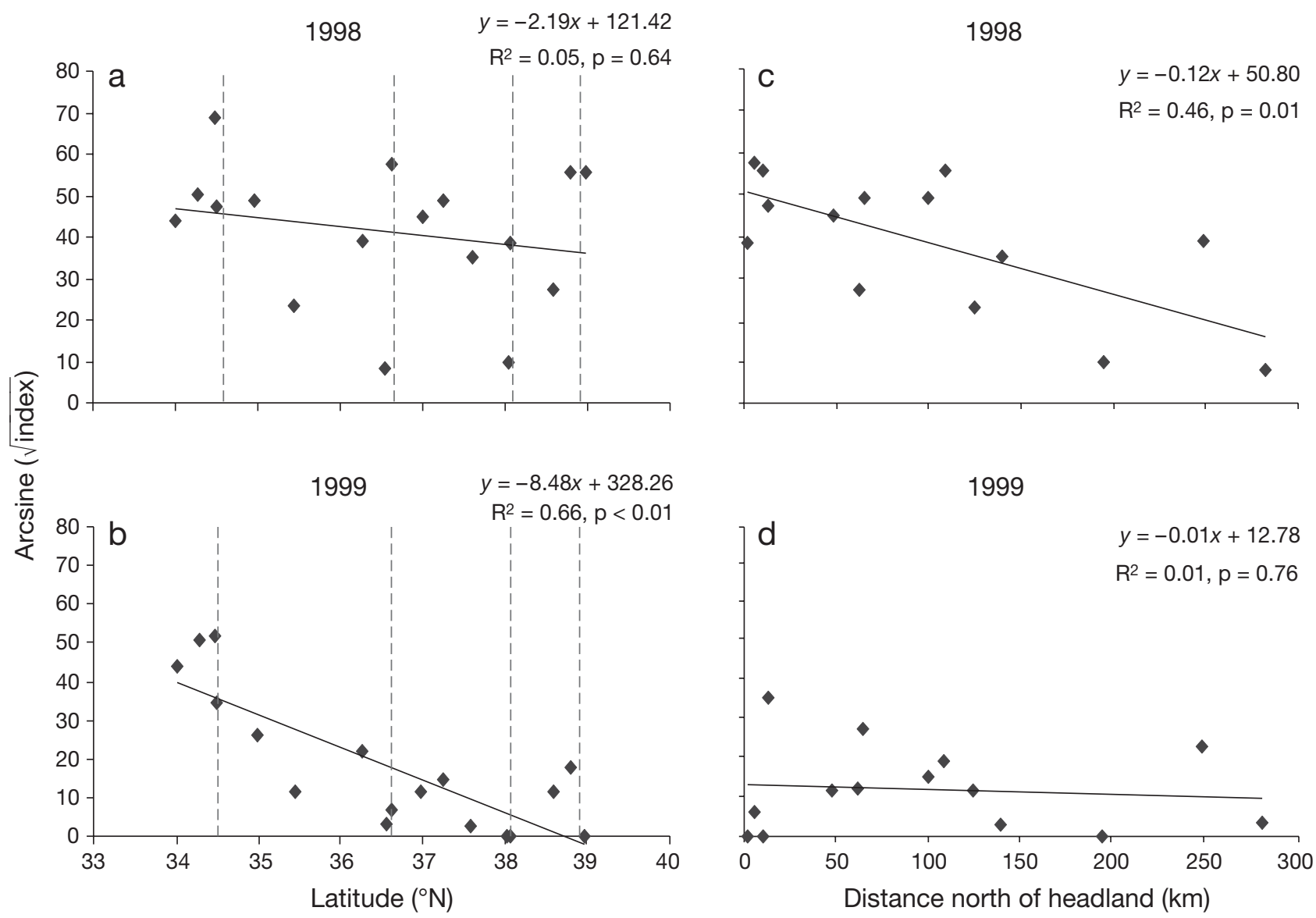

Fig. 8. Emerita analoga. Correlation of transformed index of recent recruitment of E. analoga with latitude in (a) 1998 and (b) 1999. Correlation of transformed index of recent recruitment with site distance north of a headland for (c) 1998 and (d) 1999. Dashed lines: location of major headlands (south to north): Point Conception, Monterey Peninsula, Point Reyes, and Point Arena 
in populations on average between June and August than between August and October. Recruitment is consistently high or low at each site, relative to other sites, within a year (Fig. 6); this suggests that a consistent mechanism operates within each year to determine site-specific recruitment and spatial variation in recruitment. However, this mechanism appears to operate differently from year to year, as evidenced by the lack of correlation between annual recruitment rates at each site. Additional data from longer-term temporal data sets would be useful in determining whether this difference among years is a result of the anomalous change between the 1997-1998 El Niño event and the 1999 La Niña event or within the realm of typical inter-annual variability.

To some extent, retention of larvae is expected because it aids in persistence of populations; populations along a linear coastline cannot persist with continuous, strong alongshore advection (Gaylord \& Gaines 2000). North of Point Conception, recruitment was negatively correlated with distance from a headland in 1998 (Fig. 8c). This pattern is consistent with the hypothesized effects of upwelling and relaxation on larval retention and redistribution with regard to coastal topography. In 1999, however, recruitment was not influenced by distance north of a headland (Fig. 8d). Likewise, recruitment magnitude was significantly lower $(\mathrm{p}<0.05)$ at northern sites in 1999 but not in 1998 (data not shown). Substantially different oceanographic conditions in 1998, as compared to 1999, likely account for this discrepancy in recruitment patterns. Hypotheses to explain these results include: (1) failure of the upwelling-relaxation process to deliver larvae due to few relaxations in 1999; (2) reduced biological productivity due to transport of nutrients or phytoplankton off-shelf during strong upwelling; and (3) reduced recruitment simply results in lower signal to noise ratio, such that we cannot detect the effect in 1999. The first hypothesis seems unlikely given that there were no significant differences in relaxation (that we could detect) between 1998 and 1999. The conditions under which reduced biological productivity could occur are described in modeling studies using a simple conveyor model of the mixed layer (Botsford et al. 2003, 2006). Given the present data, we are unable to determine whether the absence of a correlation between distance from a headland and recruitment (Fig. 8) is due to the mechanism not operating in an extreme year, or whether we simply cannot detect the effect because of low signal relative to the noise inherent in recruitment data. Regardless of the mechanism, these results suggest that the upwelling-relaxation mechanism appears to operate in a year with near average conditions, but may not operate in a year of extreme wind stress.
Although we measured only 2 yr, our results are consistent with biological and physical data collected in northern California over a longer time span. Both oceanographic and recruitment data collected from 1992 to 1999 at $38^{\circ} \mathrm{N}$ latitude (Bodega Bay) support the conclusion that 1998 was not exceptional, whereas conditions were clearly anomalous in 1999 (Lundquist et al. 2000, Schwing et al. 2002). Although average temperatures were roughly 2 to $3^{\circ} \mathrm{C}$ above the longterm average in 1998, upwelling indices were well within the confidence intervals for the 54 yr average, and relaxation events occurred with typical frequency and similar temperature-salinity signatures to those during non-El Niño years (Schwing et al. 2002). Crab recruitment was also consistent with this physical data; in 1998 Cancer spp. had their highest average seasonal recruitment of the 1992 to 1999 sampling period, and seasonal recruitment of non-cancrid crabs was in the middle of their 1992 to 1999 range of values (Lundquist et al. 2000). In contrast, 1999 was markedly unusual in that it had prolonged periods of colder water temperatures than normal at Bodega Bay. Further, only 2 minor, atypical relaxation events (defined by the temperature-salinity signals) occurred during the upwelling season, and average seasonal recruitment of both cancrid and non-cancrid crabs in 1999 was the lowest by nearly an order of magnitude of all those recorded during the 1992 to 1999 period (Lundquist et al. 2000).

As discussed above, failed egg production does not appear to explain low recruitment in 1999. However, the similarity in numbers of ovigerous crabs between years does not preclude a failure in recruitment due to problems with egg or larval development. In addition, we note that we examined recruitment, rather than settlement, and must therefore assume that no differential post-settlement mortality among populations occurred before we were able to locate recruits. Although there is no evidence to support this possibility, if post-settlement mortality varied among sites differently between 1998 and 1999, the relationship between recruitment and distance north of a headland could have been affected.

In contrast to northern California, both the magnitude and the spatial pattern of Emerita analoga recruitment at sites south of Point Conception were similar in 1998 and 1999. The magnitude of recruitment index at the 3 sites in the SCB declined from west to east in both years (Fig. 7). We had little evidence for the possible mechanism of upwelling-relaxation affecting recruitment south of Point Conception, but the nearshore oceanographic patterns reviewed above suggest specific hypotheses about the possible distribution of larvae in the SCB. Although the coastwide values for wind stress and upwelling were comparatively similar 
among years for each site in 1998 and 1999 (Fig. 4), we find distinct differences between values north and south of Point Conception with regard to the long-term averages in these locations (Fig. 3). As discussed previously, upwelling and wind stress were anomalously high north of Point Conception in 1999, but well within the range of variability experienced over the prior $54 \mathrm{yr}$ in 1998. In contrast, south of Point Conception the upwelling index was within the range of variability experienced over the prior $54 \mathrm{yr}$ in both years. Nevertheless, wind stress was still much greater in 1999 as compared to 1998. These data suggest that, unlike the region to the north of Point Conception, the mechanism controlling recruitment magnitude and spatial patterns south of Point Conception continues to operate effectively in the presence of high wind stress.

We do not know the mechanism that resulted in similar patterns of recruitment of Emerita analoga in both years in the SCB, but a decline in recruitment with distance east of Point Conception has also been observed in rockfish recruits in the SB Channel (Carr \& Syms 2006). Rockfish larvae are known to concentrate at thermal fronts (Carr \& Syms 2006), and the presence of larval and juvenile rockfishes is typically associated with warm, low salinity SCB water as opposed to recently upwelled water (Nishimoto 1999). The relationship between the different water types in the SB Channel and circulation patterns during upwelling and relaxation needs to be investigated to gain a better understanding of how circulation affects larval dispersal paths in the SCB.

Large spatial scale studies of recruitment indicate that recruitment is higher and more consistent in the southern California Bight than in northern California (Ebert et al. 1994). This difference in recruitment has been attributed to the strong offshore flows due to upwelling advecting larvae away from the coast in northern California and the cyclonic circulation retaining larvae in the SCB. In our study, the similarity in recruitment levels in southern California between years, coupled with the large decrease in recruitment in northern California between years appears to explain the differences in latitudinal correlations for 1998 and 1999 (Fig. 8). Oceanic mechanisms governing successful recruitment appeared to operate effectively in both years in the SB Channel, but only operated effectively north of Point Conception in 1998. This is particularly interesting in light of the differences in the nearshore oceanographic patterns between northern California sites and the SCB reviewed above. The anomalously high levels of upwelling and wind stress in northern California in 1999 corresponded to a significant decrease in overall recruitment and a gradient in recruitment magnitude decreasing from south to north (Fig. 8).
On the basis of our findings, and the detailed physical oceanographic studies throughout the region reviewed above, we propose that the California coast is comprised of cells of quasi-independent local populations separated by major headland structures. North of Point Conception, larvae appear to be retained near the headland associated with the southern boundary of each cell during active upwelling, then redistributed to the north during relaxation in years with average upwelling levels and the presence of wind relaxation events. This upwelling-relaxation flow leads to spatial variation in recruitment with high levels just north of each headland, then decreasing in populations further to the north (Figs. $7 \&$ 8). This mechanism for the oceanographic forcing of larval recruitment is consistent with our data across California for Emerita analoga in 1998, crab populations near Point Reyes reported by Wing et al. (1995a,b), and observed in sea urchin populations by Morgan et al. (2000) near Point Reyes and Point Arena. Furthermore, it is interesting to consider differences between the general upwellingrelaxation flow reviewed above (and predictions generated from it) and specific patterns of larval recruitment; for example Drakes Bay, just south of Point Reyes, has low recruitment, whereas Anchor Bay, just south of Point Arena, has quite high recruitment (Fig. 7). Irrespective of this, it appears that when upwelling was anomalously high in 1999 none of the northern sites had recruitment equivalent to that seen in 1998; as a result, the spatial relationship of recruitment with regard to coastal topography broke down. This breakdown does not appear to have resulted from reproductive failure of the females, but it is unknown whether larvae released in 1999 were retained in coastal eddies or moved offshore and equatorward. For example, if currents transported larvae far south, it is possible that they may have recruited into much more southerly populations (outside our study region) than would occur in a year when upwelling and relaxation are in effect. In support of this supposition, we see a significant increase in the number of recruits in southern sites in 1999 relative to 1998 (Fig. 5). Molecular genetic data is an obvious next step to examine the connectivity and determine the consequences of the apparent limits to larval exchange during most years, and possible long distance transport in anomalous years.

Regardless of the exact cause, it appears that a different oceanographic mechanism operates and regulates larval recruitment south of Point Conception. We do not know how currents impact larval movement in the SCB, but the mechanism seemed to operate similarly in both 1998 and 1999, in stark contrast to more northerly populations. Likewise, the oceanographic cell south of Point Conception had a consistent 
spatial pattern of recruitment in both 1998 and 1999, and although the wind stress and upwelling index differed between years, neither was outside the $54 \mathrm{yr}$ average (Fig. 3).

One of the implications for dispersal when the upwelling-relaxation mechanism is operating effectively at sites north of Point Conception is that populations along the coast may be effectively closed to dispersal across headlands. The degree to which cells of populations are closed through time is not known because pelagic larvae are notoriously difficult to track during dispersal (reviewed by Hellberg et al. 2002, Kinlan et al. 2005). It is generally assumed that species whose spawning times result in overlapping periods of larval duration in the plankton and are subject to similar oceanographic conditions are likely to have similar dispersal paths, insofar as dispersal is not modified by their specific behavioral characteristics (reviewed by Sponaugle et al. 2002, Siegel et al. 2003). Emerita analoga has a similar life history (benthic adults, spawning time, and pelagic larvae) to many economically important species, but is generally much easier to study. In the absence of specific data for each species, the results of this study may be applicable to the conservation and management of other species, such as Dungeness crab and red sea urchin. To date, few coastwide studies of the genetics of species with long dispersal periods have been conducted in California at the scale necessary to determine spatial subdivision with regard to topography (Moberg \& Burton 2000, Toonen 2001, Sotka et al. 2004). Our data suggest that patterns of recruitment in relation to nearshore currents driven by wind stress are fundamentally different to the north and south of Point Conception, and suggest that this area may be of particular interest in future such studies (e.g. Selkoe et al. 2006). Our study also suggests a mechanism whereby larval exchange across headlands may be restricted along the coast of California north of Point Conception. Future finescale studies of larval dispersal (e.g. Pfeiffer-Hoyt \& McManus 2005) and the interplay of coastal oceanography and population genetic structure (e.g. Baums et al. 2006, Pringle \& Wares 2007) are required to test these hypotheses.

Our study provides evidence for a potential mechanism directly affecting larval recruitment magnitude and timing. Because this study coincided with a period of strong El Niño to La Niña transition (1998 to 1999), it also provides some insight into the amount of annual variation possible for recruitment within the CCS. Our results suggest that wind stress, and its influence on upwelling and relaxation, can significantly affect recruitment magnitude and variation along the central California coastline. Long-term physical oceanographic studies coupled with recruitment dynamics on this spatial scale are needed to gain an understanding of the temporal and spatial variation in patterns of recruitment over broad geographic areas characteristic of most marine species ranges.

Acknowledgements. This research was supported by a National Science Foundation Graduate Fellowship and an NSF Dissertation Improvement Grant (DEB-9902218) to J.M.D., who was also supported as a trainee by the National Science Foundation research training group 'Nonlinear Dynamics in Biology' at UC Davis (DBI-9602226). R.J.T. was supported by NSF OCE-0623678, and L.W.B. was funded by the NSF Coastal Ocean Processes (CoOP) program (OCE9910897). We are greatly appreciative of the logistical support and access privileges provided by the caretakers and park rangers at Anchor Bay Campground, Point Reyes National Seashore, Nipomo Dunes Preserve, Jalama Beach County Park, and Zuma Beach County Park. We thank R. Grosberg, C. Lundquist, M. McManus, L. Morgan, V. Oquendo, H. Ronald and S. Wing for their discussions of this research and assistance in the field and laboratory, and G. Jensen for providing us the photo of Emerita analoga. Thanks also go to S. Morgan and 3 anonymous reviewers for insightful comments that helped to greatly improve the manuscript. This is HIMB contribution \#1292 and SOEST \#7177.

\section{LITERATURE CITED}

Barnes NB, Wenner AM (1968) Seasonal variation in mole crab Emerita analoga (Decapoda, Hippidae) in the Santa Barbara area of California. Limnol Oceanogr 13:465-475

Baums IB, Paris CB, Cherubin LM (2006) A bio-oceanographic filter to larval dispersal in a reef-building coral. Limnol Oceanogr 51:1969-1981

Boolootian RA, Giese AC, Farmanfarmaian A, Tucker J (1959) Reproductive cycles of five west coast crabs. Physiol Zool 32:213-220

Botsford LW (2001) Physical influences on recruitment to California Current invertebrate populations on multiple scales. ICES J Mar Sci 58:1081-1091

Botsford LW, Lawrence CA, Dever EP, Hastings A, Largier J (2003) Wind strength and biological productivity in upwelling systems: an idealized study. Fish Oceanogr 12: 245-259

Botsford LW, Lawrence CA, Dever EP, Hastings A, Largier J (2006) Effects of variable winds on biological productivity on continental shelves in coastal upwelling systems. Deep-Sea Res II 53:3116-3140

Brink KH, Beardsley RC, Paduan J, Limeburner R, Caruso M, Sires JG (2000) A view of the 1993-1994 California Current based on surface drifters, floats, and remotely sensed data. J Geophys Res 105:C8575-C8604

Carlon DB, Olson RR (1993) Larval dispersal distance as an explanation for adult spatial pattern in two Caribbean reef corals. J Exp Mar Biol Ecol 173:247-263

Carr MH, Syms C (2006) Recruitment: the replenishment of demersal fish populations. In: Allen L, Pondella DJ II, Horn MH (eds) The ecology of marine fishes: California and adjacent waters. University of California Press, Los Angeles, CA, p 411-427

Dever EP (2004) Objective maps of near-surface flow states near Point Conception, California. J Phys Oceanogr 34: 444-461

Dever EP, Hendershott MC, Winant CD (1998) Statistical aspects of surface drifter observations of circulation in the 
Santa Barbara Channel. J Geophys Res 103:C24781C24797

Doherty P, Fowler T (1994) An empirical test of recruitment limitation in a coral reef fish. Science 263:935-939

Dorman CE, Winant CD (2000) The structure and variability of the marine atmosphere around the Santa Barbara channel. Mon Weather Rev 128:261-282

Drake PT, McManus MA, Storlazzi CD (2005) Local wind forcing of the Monterey Bay area inner shelf. Cont Shelf Res 25:397-417

Dugan JE, Wenner AM, Hubbard DM (1991) Geographic variation in the reproductive biology of the sand crab Emerita analoga (Stimpson) on the California Coast. J Exp Mar Biol Ecol 150:63-81

Dugan JE, Hubbard DM, Wenner AM (1994) Geographic variation in life history of the sand crab, Emerita analoga (Stimpson) on the California coast: relationships to environmental variables. J Exp Mar Biol Ecol 181:255-278

Dugan JE, Hubbard DM, Lastra M (2000) Burrowing abilities and swash behavior of three crabs, Emerita analoga Stimpson, Blepharipoda occidentalis Randall, and Lepidopa californica Efford (Anomura, Hippoidea), of exposed sandy beaches. J Exp Mar Biol Ecol 255:229-245

Ebert TA, Schroeter SC, Dixon JD, Kalvass P (1994) Settlement patterns of red and purple sea urchins (Strongylocentrotus franciscanus and $S$. purpuratus) in California, USA. Mar Ecol Prog Ser 111:41-52

Efford IE (1965) Aggregations in the mole crab Emerita analoga (Stimpson). J Anim Ecol 34:63-75

Efford IE (1970) Recruitment to sedentary marine populations as exemplified by the mole crab, Emerita analoga (Decapoda, Hippidae). Crustaceana 18:293-308

Efford IE (1976) Distribution of the mole crabs in the genus Emerita (Decapoda, Hippidae). Crustaceana 30:293-308

Farrell TM, Bracher D, Roughgarden J (1991) Cross-shelf transport causes recruitment to intertidal populations in central California (USA). Limnol Oceanogr 36:279-288

Fusaro C (1978) Growth rate of the mole crab, Emerita analoga, (Hippidae) in two different environments. Fish Bull 76:369-375

Gan JP, Allen JS (2002a) A modeling study of shelf circulation off northern California in the region of the Coastal Ocean Dynamics Experiment. 2. Simulations and comparisons with observations. J Geophys Res107:C3184, doi:10.1029/ 2001JC001190, 2002

Gan JP, Allen JS (2002b) A modeling study of shelf circulation off northern California in the region of the Coastal Ocean Dynamics Experiment: response to relaxation of upwelling winds. J Geophys Res107:C3123

Gaylord B, Gaines SD (2000) Temperature or transport? Range limits in marine species mediated solely by flow. Am Nat 155:769-789

Graham WM (1993) Spatiotemporal scale assessment of an upwelling shadow in northern Monterey Bay, California. Estuaries 16:83-91

Graham WM, Field JG, Potts DC (1992) Persistent 'upwelling shadows' and their influence on zooplankton distributions. Mar Biol 114:561-570

Graham WM, Largier JL (1997) Upwelling shadows as nearshore retention sites: the example of northern Monterey Bay. Cont Shelf Res 17:509-532

Harms S, Winant CD (1998) Characteristic patterns of the circulation in the Santa Barbara Channel. J Geophys Res 103:C3041-C3065

Hellberg ME, Burton RS, Neigel JE, Palumbi SR (2002) Genetic assessment of connectivity among marine populations. Bull Mar Sci 70:273-290
Johnson MW, Lewis WM (1942) Pelagic larval stages of the mole crabs Emerita analoga (Stimson), Blepharipoda occidentalis Randall, and Lepidopa myops Stimpson. Biol Bull 83:67-87

Kaplan DM, Largier J, Botsford LW (2005) HF radar observations of surface circulation off Bodega Bay (northern California, USA). J Geophys Res 110:C10020

Kinlan BP, Gaines SD (2003) Propagule dispersal in marine and terrestrial environments: a community perspective. Ecology 84:2007-2020

Kinlan BP, Gaines SD, Lester SE (2005) Propagule dispersal and the scales of marine community process. Divers Distrib 11:139-148

Largier JL, Magnell BA, Winant CD (1993) Subtidal circulation over the northern California shelf. J Geophys Res 98:C18147-C18179

Lundquist CJ, Botsford LW, Morgan LE, Diehl JM, Lee T, Lockwood DR, Pearson EL (2000) Effects of El Niño and La Niña on local invertebrate settlement in northern California. Calif Coop Ocean Fish Investig Rep 41:167-176

Lynn RJ, Bliss KA, Eber LE (1982) Vertical and horizontal distributions of seasonal mean temperature, salinity, sigma-t, stability, dynamic height, oxygen, and oxygen saturation in the California Current, 1950-1978. CalCOFI Atlas 30

Lynn RJ, Baumgartner T, Garcia J, Collins CA and 8 others (1998) The state of the California current, 1997-1998: transition to El Niño conditions. Calif Coop Ocean Fish Investig Rep 39:25-49

Menge BA (2000) Recruitment vs. postrecruitment processes as determinants of barnacle population abundance. Ecol Monogr 70:265-288

Miller BA, Emlet RB (1997) Influence of nearshore hydrodynamics on larval abundance and settlement of sea urchins Strongylocentrotus franciscanus and $S$. purpuratus in the Oregon upwelling zone. Mar Ecol Prog Ser 148:83-94

Moberg PE, Burton RS (2000) Genetic heterogeneity among adult and recruit red sea urchins, Strongylocentrotus franciscanus. Mar Biol 136:773-784

Morgan LE, Wing SR, Botsford LW, Lundquist CJ, Diehl JM (2000) Spatial variability in red sea urchin (Strongylocentrotus franciscanus) recruitment in northern California. Fish Oceanogr 9:83-98

Nishimoto M (1999) Distributions of late-larval and pelagic juvenile rockfishes in relation to water masses around the Santa Barbara Channel Islands in early summer, 1996. In: Love M, Nishimoto M, Schroeder D, Caselle J (eds) The ecological role of natural reefs and oil and gas production platforms on rocky reef fishes in southern California. 5th Calif Island Symp, OSC Study MMS 99-0038. Minerals Management Service, Santa Barbara, CA, p 483-491

Paduan JD, Rosenfeld LK (1996) Remotely sensed surface currents in Monterey Bay from shore-based HF radar (Coastal Ocean Dynamics Application Radar). J Geophys Res 101:C20669-C20686

Parrish RH, Nelson CS, Bakun A (1981) Transport mechanisms and reproductive success of fishes in the California current. Biol Oceanogr 1:175-203

Pfeiffer-Hoyt AS, McManus MA (2005) Modeling the effects of environmental variability on Balanus glandula larval development. J Plankton Res 27:1211-1228

Pringle JM, Wares JP (2007) Going against the flow: maintenance of alongshore variation in allele frequency in a coastal ocean. Mar Ecol Prog Ser 335:69-84

Rosenfeld LK, Schwing FB, Garfield N, Tracy DE (1994) Bifurcated flow from an upwelling center: a cold water source for Monterey Bay. Cont Shelf Res 14:931-964

Roughgarden J, Iwasa Y, Baxter C (1985) Demographic 
theory for an open marine population with space-limited recruitment. Ecology 66:54-67

Roughgarden J, Pennington JT, Stoner D, Alexander S, Miller K (1991) Collisions of upwelling fronts with the intertidal zone: The cause of recruitment pulses in barnacle populations of central California (USA). Acta Oecol 12:35-52

Schwing FB, Murphree T, deWitt L, Green PM (2002) The evolution of oceanic and atmospheric anomalies in the northeast Pacific during the El Niño and La Niña events of 1995-2001. Prog Oceanogr 54:459-491

Selkoe KA, Gaines SD, Caselle JE, Warner RW (2006) Current shifts and kin aggregation explain genetic patchiness in fish recruits. Ecology 87:3082-3094

Send U, Beardsley RC, Winant CD (1987) Relaxation from upwelling in the Coastal Ocean Dynamics Experiment. J Geophys Res 92:C1683-C1698

Shanks AL, Grantham B, Carr MH (2001) Propagule dispersal distance and the size and spacing of marine reserves. Ecol Appl 13:S159-S169

Siegel DA, Kinlan BP, Gaylord B, Gaines SD (2003) Lagrangian descriptions of marine larval dispersion. Mar Ecol Prog Ser 260:83-96

Siegel PR (1984) Food-induced size-specific molt synchrony of the mole crab, Emerita analoga (Stimpson). Biol Bull 167:579-589

Sokal RR, Rohlf FJ (1981) Biometry: the principles and practice of statistics in biological research. W.H. Freeman, New York

Sotka EE, Wares JP, Barth JA, Grosberg RK, Palumbi SR (2004) Strong genetic clines and geographical variation in gene flow in the rocky intertidal barnacle Balanus glandula. Mol Ecol 13:2143-2156

Sponaugle S, Cowen RK, Shanks A, Morgan SG and 7 others (2002) Predicting self-recruitment in marine populations:

Editorial responsibility: Steven Morgan (Contributing Editor) Bodega Bay, California, USA biophysical correlates and mechanisms. Bull Mar Sci 70 Suppl: $341-375$

Storlazzi CD, McManus MA, Figurski JD (2003) Long-term, high-frequency current and temperature measurements along central California: insights into upwelling/relaxation and internal waves on the inner shelf. Cont Shelf Res 23:901-918

Toonen RJ (2001) Genetic analysis of recruitment and dispersal patterns in the porcelain shore crab, Petrolisthes cinctipes. PhD dissertation, Univ. of California, Davis

Trenberth KE, Large WG, Olson JG (1990) The mean annual cycle in global ocean wind stress. J Phys Oceanogr 20: $1742-1760$

Washburn L, Swenson MS, Largier JL, Kosro PM, Ramp SR (1993) Cross-shelf sediment transport by an anticyclonic eddy off nothern California. Science 261:1560-1564

Winant CD, Alden DJ, Dever EP, Edwards KA, Hendershott MC (1999) Near-surface trajectories off central and southern California. J Geophys Res 104:C15713-C15726

Winant CD, Dever EP, Hendershott MC (2003) Characteristic patterns of shelf circulation at the boundary between central and southern California. J Geophys Research 108:C3021

Wing SR, Botsford LW, Largier JL, Morgan LE (1995a) Spatial structure of relaxation events and crab settlement in the northern California upwelling system. Mar Ecol Prog Ser 128:199-211

Wing SR, Largier JL, Botsford LW, Quinn JF (1995b) Settlement and transport of benthic invertebrates in an intermittent upwelling region. Limnol Oceanogr 40:316-329

Wing SR, Botsford LW, Ralston SV, Largier JL (1998) Meroplanktonic distribution and circulation in a coastal retention zone of the northern California upwelling system. Limnol Oceanogr 43:1710-1721

Submitted: June 27, 2006; Accepted: August 12, 2007

Proofs received from author(s): October 17, 2007 